
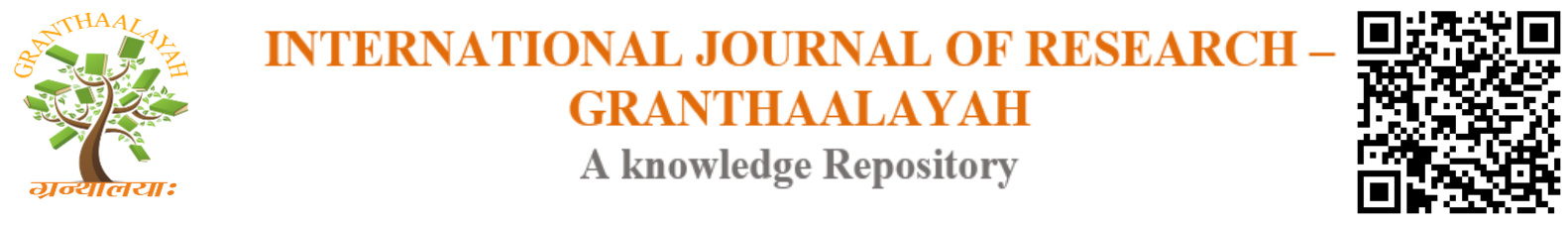

Management

\title{
A CASE STUDY AND ANALYSIS OF GARMENT RETAILING WITH CONSUMER BEHAVIOR
}

\author{
Manish Dubey ${ }^{* 1}$, Dr. Siddharth Saini ${ }^{2}$, Dr. Srishti Umekar ${ }^{3}$ \\ ${ }^{* 1}$ Ph.D. (Pursuing), Aisect University, Bhopal, INDIA \\ 2, 3 Assistant Professor, Aisect University, Bhopal, INDIA
}

DOI: https://doi.org/10.29121/granthaalayah.v4.i11.2016.2428

\section{ABSTRACT}

These are testified through the escalating figure of the garment market is also by the growing tally of fashion brands and retailers whose has occupied substantial share of the country's retail space. The apparel industry reflects people's lifestyles and shows their social and economic status. The apparel industry is India's second largest industry after the IT industry. Young consumer group have gained significant importance from marketers in recent years because of their purchasing power.

Keywords:

Consumer behavior, consumer purchase preference, Garment Retailing.

Cite This Article: Manish Dubey, Dr. Siddharth Saini, and Dr. Srishti Umekar, "A CASE STUDY AND ANALYSIS OF GARMENT RETAILING WITH CONSUMER BEHAVIOR" International Journal of Research - Granthaalayah, Vol. 4, No. 11 (2016): 111-114.

\section{INTRODUCTION}

The actions a person takes in purchasing and using products and services, including the mental and social processes that precede and follow these actions can be called as a consumer behavior. Consumer purchase decision process: Behind the visible act of making a purchase, lies a decision that must be investigated. The purchase decision process is the stages a buyer phases through in making choices about which products and services to buy. These are five stages of consumer behavior (i) problem recognition (ii) information search (iii) alternative evaluation (iv) purchase decision (v) post purchase behavior on the basis of that a consumer takes decision on a general basis.

\section{LITERATURE REVIEW}

The various studies related to consumer behaviors in India and abroad are being referred by the researcher. The general field is one which has been extensively studied, and the research is discussed and reviewed by Wahyuningsih and Chris Dubelaar (2004) in his paper 'Consumer 
Behavior and Satisfaction' of Monash University. In their studies they have concluded that to satisfy their customers, companies need to identify clearly each segment of consumers whether they are passive, rational-active, or relational-dependent consumers.

Retailing is set activities that markets products or services to the final consumers for their personal or households use. This is a Greek word which means "to cut the bulk in to pieces." In India this industry is present since ages. The organized garment retailing is the sale of garment products to consumers. The concept of organized retailing gained momentum in 1980 and when Mother's Dairy introduced vegetables and milk at the retail outlets in New Delhi. Later, many national and international players entered the arena (Rajmohan 2007)

The arena of organized retailing came after liberalization in 1991. According CMIE report the retail growth doubled from 1990 to 1999. In India there are more than 15 million retailers , operating in the form of 'mom pop' outlets spread over more than 31 million square meters area, generating sales of USD 11 billion in 2007-2008 (Rajmohan 2007) .

\section{RETAIL SCENARIO}

This can be sub divided in to brand and non - brand. The branded retail sector is not more than $10 \%$ of the total. A retailer (whether shop owner or mall) has to keep a higher margin for branded garments than for unbranded to take care of returns on his investments as well as discount on end of season sales or out of fashion stocks and overheads. The retail markup is 50 $\%$ for branded and $25 \%$ for non-branded garments. On this basis of the retail market for garments can be estimated to be around Rs. Four to Five trillion or around Rs. 500000 crore. With malls coming up all over Indian metros, retail trade in garments is getting better organized than earlier. Attention is now shifting to ' $\mathrm{B}$ ' class and ' $\mathrm{C}$ ' class cities as well as the rural sector. With the growth of the economy, thanks to economic liberalization, the result of which is percolating to our farm lands as well as spread of education in the rural population is fast picking up to the urban level. Farm produce is being is better organized to reduce wastage and increase the income of farmers, Rural in deftness is being better bank managed than the earlier system of dependence on money lender sharks.

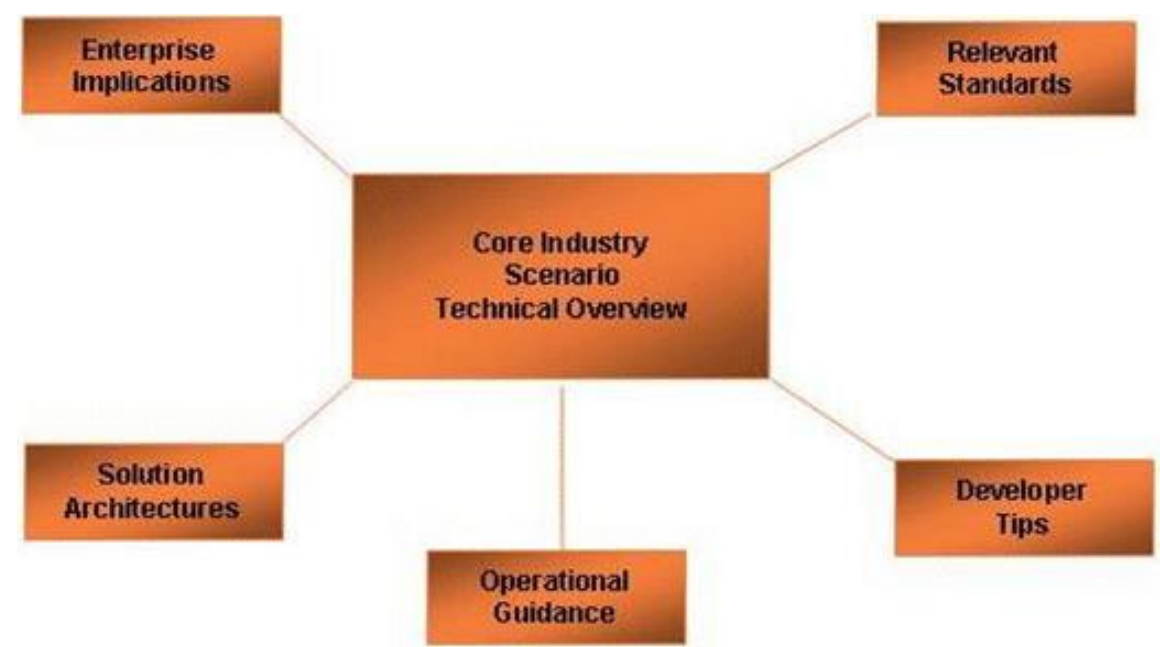

Figure 1: Scenario Technical overview 


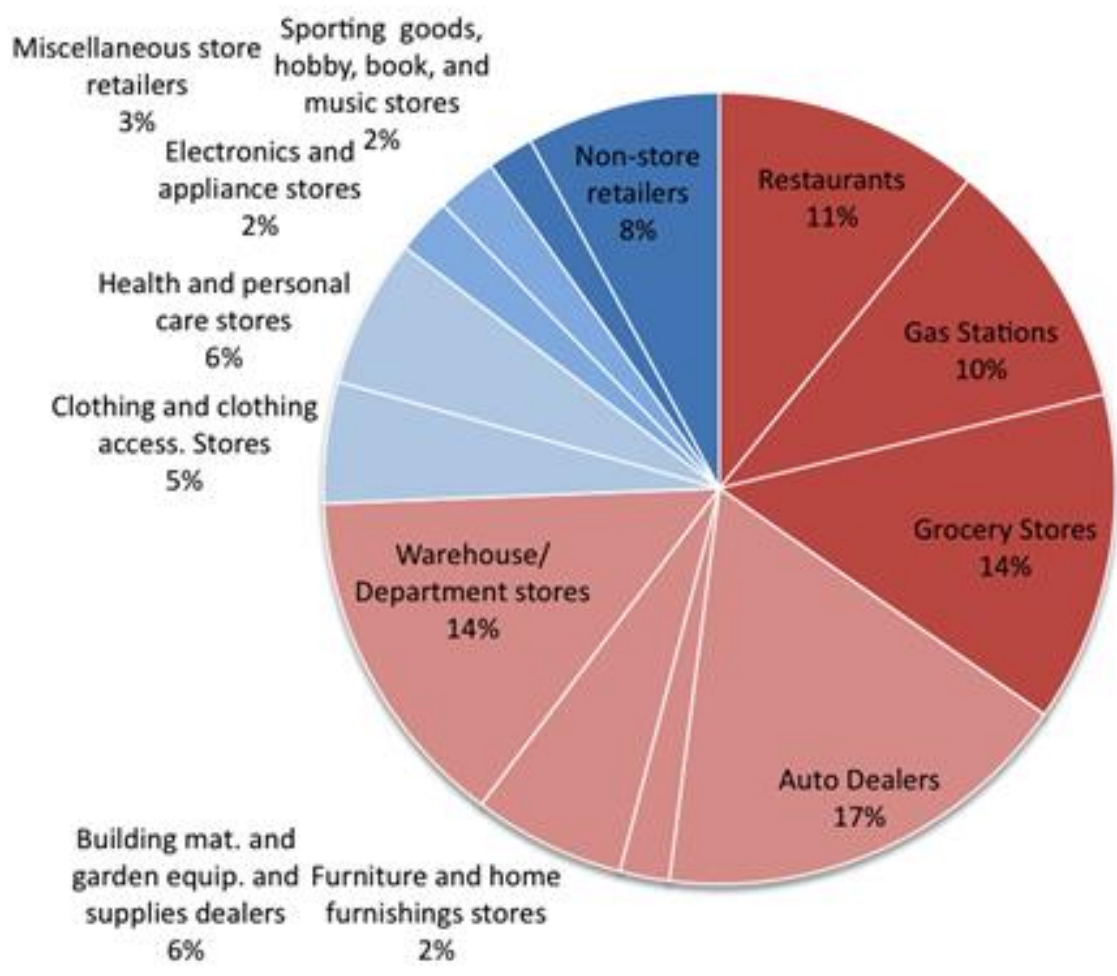

Figure 2: Retail sales

\section{HISTORY}

The history of apparel in India dates back to the use of mordant dyes and printing blocks around three thousand BC. The foundations of the India's textile trade with other countries started as early as the second century BC. A hoard of block printed and resists dyed fabrics, primarily of Guajarati origin, discovered in the tombs of Fostat, Egypt, are the proof of large scale Indian export of cotton textiles to the Egypt in medieval periods. During the 13 century, Indian silk was used as barter for spices from the western countries.

\section{GROWTH OF INDIAN GARMENT INDUSTRY}

The industry has already given ample hint of ingenuity, as is evident from the revival of consumer enthusiasm in the seemingly stagnant menswear segment, besides remarkable growth in categories like sportswear, casual wear and party wear. The apparel market has grown fifteen percent to INR one thousand two hundred and twenty four billion. The country's organized retail is booming because of increasing private incomes and changing lifestyles and consumption pattern of consumers is having a positive effect on the apparel industry. There has been a rapid increase in the market size of ready to wear clothing and lifestyle apparel brands.

\section{METHODOLOGY}

To analyze the consumer behavior there are number of research methodologies are available. But keeping proposed research objectives, a particular methodology is prepared. The methodology contents three things as data collection technique (Primary data and Secondary data), Sampling 
technique and sample size. For the study the method of primary and secondary data both will be adopted. Since in the study area not much work has been done yet, therefore in the scarcity of the availability of published data the primary survey has to be done. To collect the primary data a structured questionnaire will be framed and monitor in the Jhansi region which is the proposed area. Stratified random sampling will be carried out to monitor the data. The sample size is expected to have at least 1000 respondents in order to receive relevant conclusion about the research work because the garment retail consumer is a universal phenomena and a very large strata.

To analyze the data simple statistical technique will be adopted such as; Descriptive statistics will be used to know the current status of the consumer behavior. Frequency table will be made to analyze the characteristics of consumer. The factor analysis will be applied to find out the group of factors which influence and determine the consumer behavior in the study area.

\section{REFERENCES}

[1] Aaker, D. A. (1996).Measuring brand equity across products and markets. California Management Review, 38 (1), 100-120.

[2] Banks, J., \& Moorthy, S. (1999) “A model of price promotion”. International Journal of Industrial Organization, Vol. 17, pp. 371-398.

[3] Bawa, K. \& Shoemaker, R.W. (1987).The effects of a direct mail coupon on brand choice behavior.Journal of Marketing Research. 24, 370-376

[4] Belch EA, Belch EL. (1996), The effects of reference prices in retail advertisements. Journal of Marketing; 45(2), 61-69.

[5] Belch EA, Belch EL. (1996), The effects of reference prices in retail advertisements. Journal of Marketing; 45, 61-69.

[6] Blackwell, R.D., Miniard, P.W. and Engel, J.F. (2001), "Consumer Behavior", 9th ed. Fort Worth, TX: HarcourtCollege Publishers.

[7] Blattberg RC, Neslin, S.A. (1990).Sales Promotion, Concepts, Methods and Strategies.New Jersey, Englewood Cliffs.Prentice Hall.

[8] Barry Berman, Joel Evans R. (2007), -Retail Management a Strategic Approach\|, tenth edition Pearson Education Inc., Dorling Kindersley Publishing Inc. 